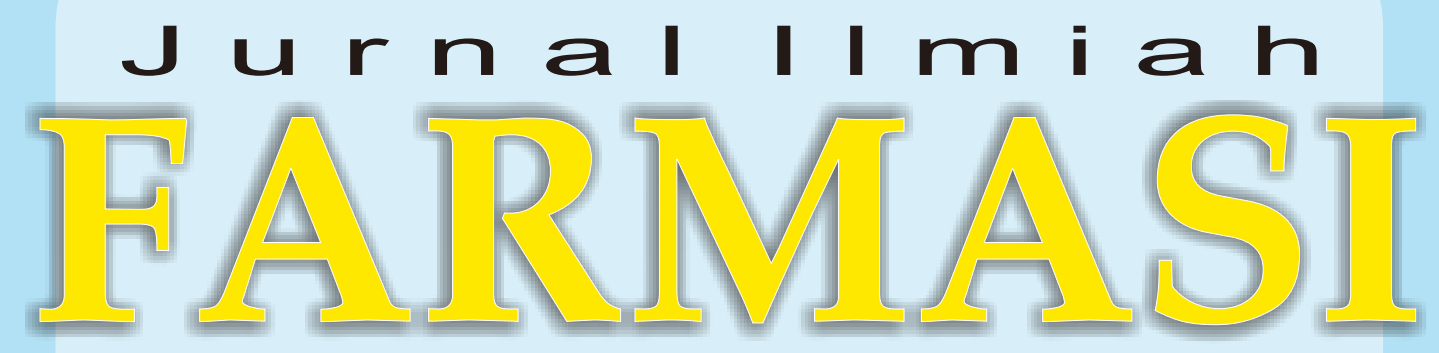

(Scientific Journal of Pharmacy) 
JURNAL ILMIAH FARMASI

(SCIENTIFIC JOURNAL OF PHARMACY)

PIMPINAN UMUM/ PENANGGUNG JAWAB

Dekan Fakultas Matematika dan Ilmu Pengetahuan Alam

Universitas Islam Indonesia

WAKIL PIMPINAN UMUM/ WAKIL PENANGGUNG JAWAB

Ketua Jurusan Farmasi FMIPA UII

\section{MITRA BESTARI}

1. Prof. Dr. Wiryatun Lestariana, Apt

2. Prof. Dr. Zullies Ikawati, Apt

3. Prof. Dr. Sudibyo Martono, Apt

4. Dr. Tedjo Yuwono, Apt

5. Prof. Dr. Dachriyanus, Apt

6. Prof. dr. Iwan Dwiprahasto, MMedSc, PhD

7. Prof. Dr. Lukman Hakim M.Sc., Apt

8. Prof. Dr. Achmad Fudholi, DEA, Apt

9. Prof. Dr. Ibnu Gholib Gandjar, DEA., Apt

\begin{tabular}{ll} 
& \multicolumn{1}{c}{ DEWAN EDITOR } \\
Ketua & : Saepudin, M.Si., Apt \\
Sekretaris & : Rochmy Istikharah, M.Sc., Apt. \\
Anggota & : Vitarani Dwi Ananda Ningrum, M.Si., Apt \\
& Okti R. Mafruhah, MSc., Apt \\
& Dimas Adhi Pradana, MSc., Apt. \\
& Fithria DA. Suryanegara, MSc., Apt. \\
& Ari Wibowo, S.Farm., Apt \\
& Arba Pramudita Ramadani, MSc., Apt. \\
& Oktavia Indrati, S.Farm., Apt.
\end{tabular}

Penerbit

Jurusan Farmasi Fakultas Matematika dan IImu Pengetahuan Alam Universitas Islam Indonesia

Alamat Penerbit Jurusan Farmasi FMIPA UII

Jl. Kaliurang Km. 14,4 Yogyakarta 55584

Telp. (0274) 896439 ext. 3047

Email: jif@uii.ac.id 


\title{
KARAKTERISASI FISIKOKIMIA DAN LAJU DISOLUSI DISPERSI PADAT IBUPROFEN DENGAN PEMBAWA POLIETILENGLIKOL 6000
}

\author{
Erizal Zaini*, Rahmi Nofita, Salman, Irna Kurniati \\ Laboratorium Teknologi Farmasi, Fakultas Farmasi, Universitas Andalas \\ Kampus Limau Manis, Sumatera Barat, Indonesia \\ *e-mail: erizal_faua@yahoo.co.id
}

\begin{abstract}
Solid dispersions of the antiinflamation drug ibuprofen and polyethylene glycol 6000 (PEG $6000)$ were prepared by the melting method in order to increase the dissolution rates of this poorly water-soluble compound. The temperature/composition phase diagram of binary system was analyzed by termal analysis hot-stage microscopy, showing an eutectic formation. Polarized light hot stage microscopy and X-ray-powder diffraction confirmed, that solid dispersion technique decrease the crystalliny of ibuprofen after melting and solidifying of a $4 / 6(\mathrm{w} / \mathrm{w})$ mixture of ibuprofen and polyethylene glycol 6000 respectively, which the results enhanced dissolution rates compared to the physical mixtures and ibuprofen intact. However, no such chemical interactions in the solid state were confirmed by FTIR spectra which showed the presence of ibuprofen crystalline in solid dispersion.
\end{abstract}

Keywords: solid dispersions, ibuprofen, polyethylene glycol 6000 